\title{
Metode Kerja Kelompok sebagai upaya Peningkatan Kompetensi Guru dalam Menyusun Soal Tes Semester di SDN Kalibanteng Kulon 02
}

\section{Semarang}

\author{
Sugiwanti \\ SDN Kalibanteng Kulon 02 \\ sugiwanti.sarwono1@gmail.com
}

\begin{abstract}
The act of making questions as an assessment instrument cannot be carried out arbitrarily, to improve the quality of teachers in making questions, it is necessary to know about making tests. However, it was found that there were many written test questions for the semester that the teachers of SDN Kalibanteng Kulon 02 Semarang City did not comply with the rules for writing questions. Of the 18 teachers there are only 5 teachers or $28 \%$ of teachers who are able to make written test questions according to the rules. Written test items that are not correct from the point of view of the rules for writing questions must be corrected or replaced with new items. This of course requires the role of the principal by carrying out academic supervision activities that can be done using group techniques through the Group Work method which can be done by holding group discussions. This is intended to answer problems 1) How is the implementation of the group work method as an effort to increase teacher competence in preparing semester test questions at SDN Kalibanteng Kulon 02 Semarang City for the 2020/2021 academic year?. 2) Can the implementation of the group work method improve teacher competence in preparing semester test questions at SDN Kalibanteng Kulon 02 Semarang City for the 2020/2021 school year? These problems are discussed through school action research which is carried out through 2 cycles with each cycle the stages are planning, action, observation and reflection. The results showed: 1) The implementation of the group work method as an effort to increase teacher competence in preparing semester test questions was carried out by dividing groups of teachers under the supervision of the principal, each group was given material on the preparation of a good semester test and according to the rules previously given. an explanation by the supervisor, each group reviewed and discussed how to prepare a good semester test based on the results of the test preparation that had been made by each member, the results of the group discussion were then presented and commented on by other groups. 2) The implementation of the group work method can improve teacher competence in preparing semester test questions, this can be seen from the increase in the results of teacher professionalism in classroom administration management per cycle where in the first cycle there are 12 teachers or $66 \%$ and in the second cycle there are 17 teachers or $94 \%$. These results indicate that these results are in line with expectations. An increase also occurred in teacher activities in participating in mini workshops where in the first cycle there were 11 teachers or $61 \%$ and in the second cycle there were 16 teachers or $89 \%$. The increase in the implementation of mini workshops is an effective way for school principals to improve the ability of teachers to develop learning tools.
\end{abstract}

Keywords: Method, Group Work, Improvement, Competence, Teacher, Composing, Test Questions, Semester.

\footnotetext{
ABSTRAK

Tindakan membuat soal sebagai instrumen penilaian tidak bisa dilaksanakan secara sembarangan, untuk meningkatkan kualitas guru dalam membuat soal maka perlu pengetahuan tentang pembuatan tes. Namun ditemukan banyak soal tes tertulis untuk semester yang buat guru SDN Kalibanteng Kulon 02 Kota Semarang belum sesuai dengan kaidah penulisan soal. Dari 18 guru hanya ada 5 guru atau $28 \%$ guru yang mampu membuat soal tes tertulis yang sesuai auturan. Butir soal tes tertulis yang belum benar dari sudut pandang kaidah penulisan soal harus segera diperbaiki atau diganti dengan butir soal yang baru. Hal ini tentunya membutuhkan peran dari kepala sekolah denan melakukan kegiatan supervisi akademik yang dapat dilakukan dengan teknik kelompok melalui metode Kerja Kelompok yang bisa dilakukan dengan mengadakan diskusi kelompok (group discussion). Ini dimaksudkan untuk menjawab permasalahan 1) Bagaimanakah pelaksanaan metode kerja kelompok sebagai upaya peningkatan kompetensi guru dalam menyusun soal tes semester di SDN
} 
Kalibanteng Kulon 02 Kota Semarang tahun pelajaran 2020/2021?. 2) Apakah pelaksanaan metode kerja kelompok dapat meningkatkan kompetensi guru dalam menyusun soal tes semester di SDN Kalibanteng Kulon 02 Kota Semarang tahun pelajaran 2020/2021? Permasalahan tersebut di bahas melalui penelitian tindakan sekolah yang dilakukan melalui 2 siklus dengan setiap siklus tahapannya adalah perencanaan, tindakan, observasi dan refleksi. Hasil penelitian menunjukkan: 1) Pelaksanaan metode kerja kelompok sebagai upaya peningkatan kompetensi guru dalam menyusun soal tes semester dilakukan dengan melakukan pembagian kelompok pada guru dalam supervisi yang dilakukan kepala sekolah, setiap kelompok diberikan bahan tentang penyusunan tes semester yang baik dan sesuai kaidah dengan sebelumnya diberikan penjelasan oleh supervisor, setiap kelompok mengjkaji dan berdiskusi tentang cara menyusun tes semester yang baik didasarkan hasil penyusan tes yang telah dibuat anggota masing, hasil diskusi kelompok kemuadian diperesentasikan dan dikomentari oleh kelompok lain. 2) Pelaksanaan metode kerja kelompok dapat meningkatkan kompetensi guru dalam menyusun soal tes semester, hal ini dapat dilihat dari peningkatan hasil profesionalias guru dalam pengelolaan administrasi kelas per siklus dimana pada siklus I ada 12 guru atau 66\% dan pada siklus II ada 17 guru atau 94\%. Hasil tersebut menunjukkan bahwa hasil tersebut sesuai dengan yang diharapkan. Peningkatan juga terjadi pada aktivitas guru dalam mengikuti mini worskhsop dimana pada siklus I ada 11 guru atau $61 \%$ dan siklus II ada 16 guru atau 89\%. Peningkatan tersebut pelaksanaan mini workshop menjadi salah satu cara yang efektif bagi kepala sekolah dalam meningkatkan kemampuan guru dalam menyusun perangkat pembelajaran.

Kata Kunci: Metode, Kerja Kelompok, Peningkatan, Kompetensi, Guru, Menyusun, Soal Tes, Semester.

\section{PENDAHULUAN}

Pendidikan adalah upaya sadar dan tanggungjawab untuk memelihara, membimbing dan mengarahkan pertumbuhan dan perkembangan kehidupan manusia, agar ia memiliki makna dan tujuan hidup yang hakiki (Ramayulis, 2014: 195). Sebagai suatu proses, pendidikan bertujuan untuk menimbulkan perubahan-perubahan perilaku yang meliputi pengetahuan, kecakapan, pengertian, sikap, ketrampilan dan sebagainya. Untuk mengetahui perubahan perilaku siswa meliputi pengetahuan, kecakapan, pengertian, sikap ketrampilan dan sebagainya, seorang guru perlu melakukan kegiatan penilaian hasil pengalaman belajar siswa. Oleh karena itu penilaian sebagai titik sentral dalam proses belajar mengajar.

Penilaian hasil belajar dapat dibedakan menjadi 2 macam yaitu tes dan non tes. Tes ada yang diberikan secara lisan (menuntut jawaban secara lisan) ini dapat dilakukan secara individu maupun kelompok, ada tes tulisan (menuntut jawaban dalam bentuk tulisan), tes ini ada yang disusun secara obyektif dan uraian dan tes tindakan (menuntut jawaban dalam bentuk perbuatan).

Berdasarkan data awal, penulis banyak menemukan soal tes tertulois untuk semester yang buat guru SDN Kalibanteng Kulon 02 Kota Semarang belum sesuai dengan kaidah penulisan soal, misalnya belum menggunakan ejaan Bahasa Indonesia yang disempurnakan (EYD), pilihan jawaban dalam soal belum homogen, konstruksi soal belum dirumuskan secara jelas dan tegas, pernyataan dalam lajur kiri dan lajur kanan pada bentuk soal menjodohkan tidak sejenis, dan sebagainya. Soal tes tertulis tersebut dibuat oleh guru di sekolah untuk kegiatan ulangan harian, ulangan tengah semester dan akhir semester. Dari 18 
guru hanya ada 5 guru atau $28 \%$ guru yang mampu membuat soal tes tertulis yang sesuai auturan. Butir soal tes tertulis yang belum benar dari sudut pandang kaidah penulisan soal harus segera diperbaiki atau diganti dengan butir soal yang baru.

Fenomena Menyusun Soal Tes Semester di SDN Kalibanteng Kulon 02 kota Semarang yang kurang maksimal tentunya membutuhkan peran dari kepala sekolah dengan melakukan kegiatan supervisi akademik yang dapat dilakukan denan teknik kelompok melalui metode Kerja Kelompok yang bisa dilakukan dengan mengadakan diskusi kelompok (group discussion), diselenggarakan dengan mengundang atau mengumpulkan guru-guru bidang studi sejenis atau yang berlainan sesuai dengan keperluannya untuk menganalisis dan membimbing cara menyusun soal tes semester yang baik.

Berdasarkan latar belakang di atas peneliti tertarik untuk mengadakan penelitian tindakan sekolah tentang "Metode Kerja Kelompok Sebagai Upaya Peningkatan Kompetensi Guru dalam Menyusun Soal Tes Semester di SDN Kalibanteng Kulon 02 kota Semarang tahun pelajaran 2020/2021"

Kepala sekolah sebagai supervisor satu-satunya orang yang dapat membantu perkembangan anggota atau stafnya dalam usaha meningkatkan mutu pendidikan di sekolah. Kepala sekolah sebagai supervisor harus diwujudkan dalam kemampuan menyusun, dan melaksanakan program supervisi pendidikan, serta memanfaatkan hasilnya.

Dalam supervisi terdapat teknik supervisi kelompok yaitu Teknik yang bersifat kelompok, seperti: pertemuan orientasi guru baru, kepanitiaan kegiatan, rapat guru, studi kelompok antar guru, tukar menukar pengalaman, lokakarya (workshop), diskusi panel, seminar, simposium, demonstrasi mengajar, mengikuti kursus, organisasi jabatan dan laboratorium kurikulum (Indrafachrudi, 2013: 280-281).

Menurut Sahertian (2010: 161) dalam kerja kelompok guru-guru disekolah dapat dikelompokkan dalam satu mata pelajaran sejenis sehingga dengan begitu mereka kan lebih mudah untuk bekerjasama dan berdiskusi guna membicarakan hal-hal yang berhubungan dengan usaha pengembangan dan peranan proses belajar mengajar khususnya dalam mengelola soal tes semesteran. Sehingga soal tes semester yang biduat guru bermutu dan sesuai aturan yang berlaku.

Teknik Supervisi yang bersifat kelompok ialah teknik supervisi yang dilaksanakan dalam pembinaan guru secara bersama - sama oleh supervisor dengan sejumlah guru dalam satu kelompok .Sedangkan menurut Sagala (2010: 210) teknik kelompok adalah prosedur yang menekankan pada kerja sama dalam kelompok dalam memecahkan suatu masalah yang dirasakan penting. 
Kompetensi menjadi salah satu perangkat yang jangan pernah sampai dilupakan oleh guru professional. Kompetensi guru (teacher competency) bermakna "the ability of a teacher responsibility perform has or her duties appropriately" (kompetensi merupakan kemampuan seorang guru ajar dalam melaksanakan kewajiban-kewajibannya diemban secara bertanggung jawab dan layak) (Usman, 2012: 14).

Menurut Undang - Undang Republik Indonesia nomor 14 tahun 2005 tentang Guru dan Dosen bab IV pasal 10 ayat 1 bahwa yang dimaksud kompetensi guru meliputi kompetensi pedagogik, kompetensi kepribadian, kompetensi sosial, dan kompetensi profesional yang diperoleh melalui pendidikan profesi (Undang - Undang Republik Indonesia nomor 14 tahun 2005 : 9). Kompetensi pedagogik dalam standar nasional pendidikan, penjelasan pasal 28 ayat 3 butir (a) adalah kemampuan mengelola pembelajaran peserta didik yang meliputi pemahaman terhadap peserta didik, perancangan, dan pelaksanaan pembelajaran, evaluasi hasil belajar, dan pengembangan peserta didik untuk mengaktualisasikan berbagai potensi yang dimilikinya (Asmani, 2009: 59).

Salah satu bentuk kompetensi guru adalah evaluasi pembelajaran, Menilai atau evaluasi merupakan suatu proses yang sengaja direncanakan untuk memperoleh informasi atau data; berdasarkan data tersebut kemudian dicoba membuat suatu keputusan. Sudah barang tentu informasi atau data yang dikumpulkan itu haruslah data yang sesuai dan mendukung tujuan evaluasi yang direncanakan (Purwanto, 2012: 3).

Kegiatan penilaian atau evaluasi mencakup penilaian terhadap kemajuan belajar peserta didik dalam aspek pengetahuan, ketrampilan dan sikap sesudah mengikuti proses pembelajaran (Zuhairini, dkk, 2011: 146). Dengan melakukan evaluasi guru dapat mengetahui tingkat kemajuan belajar peserta didik, menempatkan peserta didik dalam situasi belajar mengajar yang tepat dan memperoleh umpan balik atau feed back dan KBM yang dilakukan.

Kegiatan supervisi dengan metode kerja kelompok dilaksanakan untuk meningkatkan Peningkatan kompetensi guru dalam menyusun soal tes semester yang baik berdasarkan konsep-konsep eavluasi pembelajaran dalam kependidikan. Melalui supervisi dengan metode kerja kelompok, diupayakan bahwa penyusunan soal tes semester harus memasukkan obyekobyek tes baik meliputi konstruksi materi tes dan bahasa secara lengkap. Kegiatan supervisi dengan metode kerja kelompok mampu menjadikan guru saling tukar pikiran dengan sesama dan berdiskusi untuk meneliti setiap item tes semester yang telah dibuat sehingga setiap kelemahan yang ada bisa diperbaiki secara diskusi kelompok. Lebih jelasnya peneliti gambarkan dalam gambar berikut: 
Kondisi awal:

- Kompetensi Guru dalam Menyusun Soal Tes Semester masih belum sesuai dengan kaidah penulisan soal.

- guru yang mampu membuat soal tes tertulis yang sesuai aturan. ,

- Guru dalam menyusun soal tes hanya meng-copy paste dari teman maupun internet

Kompetensi Guru dalam Menyusun Soal Tes Semester Rendah

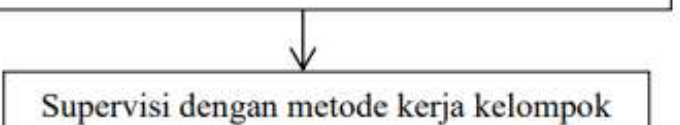

Akibat,

- Guru saling bertukar pikiran dengan supervisor dan sesama guru

- Saling melengkapi kekurangan guru lain dalam menulis soal

- Saling berdiskusi untuk mendapatkan soal tes yang baik.

Gambar 1. Kerangka Berpikir

Hipotesis tindakan dalam penelitian ini adalah terjadi pelaksanaan metode kerja kelompok dapat meningkatkan kompetensi guru dalam menyusun soal tes semester di SDN Kalibanteng Kulon 02 Kota Semarang tahun pelajaran 2020/2021.

\section{METODE PENELITIAN}

Jenis penelitian kelas ini adalah penelitian tindakan (action research). Penelitian tindakan menurut Agus Wasisto (2016: 42) adalah suatu bentuk penilaian refleksi diri yang dilakukan oleh para partisipan dalam situasi-situasi social (termasuk pendidikan) untuk memperbaiki rektak yang dilakukan sendiri. Dalam penelitian ini peneliti tindakan yang digunakan adalah penelitian tindakan sekolah (PTS).

Tempat penelitian SDN Kalibanteng Kulon 02 kota Semarang. Penelitian ini dilakukan pada tanggal 23 Januari 2021-3 April 2021. Adapun subjek dalam penelitian ini adalah seluruh guru SDN Kalibanteng Kulon 02 Kota Semarang tahun pelajaran 2020/2021 sejumlah 18 guru. Variabel penelitian terdiri atas variabel bebas dan variabel terikat. Variabel bebas (yang mempengaruhi) dalam penelitian ini adalah metode kerja kelompok sedangkan 
variabel terikatnya (yang dipengaruhi) adalah kompetensi guru dalam menyusun soal tes semester.

Penelitian tindakan sekolah ini menggunakan model Kemmis dan Mc. Taggart, dimana peneliti terdiri atas empat tahap yaitu perencanaan (planning), pelaksanaan (acting), pengamatan (observing), dan refleksi (reflecting). Hubungan keempat komponen tersebut dipandang sebagai satu siklus. Adapun alur dari penelitian ini adalah sebagai berikut:

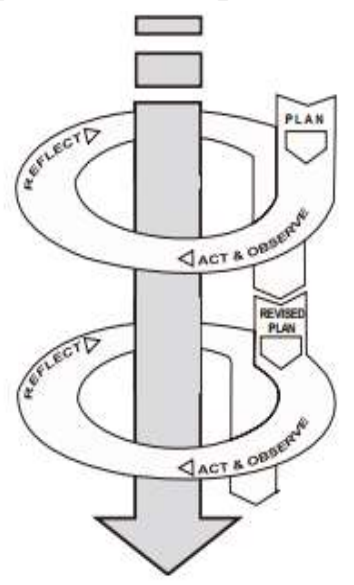

Gambar 2. Desain penelitian model Kemmis dan Mc. Taggart

Teknik Pengumpulan Data

1. Metode Observasi

Metode pengamatan (observasi), cara pengumpulan datanya terjun langsung ke lapangan terhadap objek yang diteliti, populasi (sampel) (Margono, 2010: 158).

2. Metode Dokumentasi

Metode dokumentasi yaitu mencari data mengenai hal-hal atau variabel yang berupa catatan, buku, transkip, surat kabar majalah, prasasti, notulen rapat, legger, agenda dan sebagainya (Arikunto, 2006: 206).

Analisis Data

1. Analisis Kualitatif

Data-data yang diperoleh dari penelitian baik melalui pengamatan, tes atau dengan menggunakan metode yang lain kemudian diolah dengan analtekss deskriptif untuk menggambarkan keadaan peningkatan pencapaian indikator keberhasilan tiap siklus dan untuk menggambarkan keberhasilan.

2. Analisis Kuantitatif

Data yang berbentuk kuantitatif berupa data-data yang disajikan berdasarkan angka-angka maka analtekss dilakukan dengan:

a. Penilaian Individu 
Penilain individu dihitung dengan menggunakan Analisis kualitatif persentase, yaitu:

Nilai $=\frac{n}{N} \times 100 \%$

Keterangan:

$\mathrm{N}=$ Jumlah Maksimal

$\mathrm{n}=$ Jumlah nilai yang diperoleh oleh guru

$\%=$ Tingkat prosentase yang dicapai

b. Ketuntasan Klasikal

Data yang diperoleh dari hasil kerja peserta dapat menentukan ketuntasan klasikal menggunakan Analisis deskriptif prosentase, dengan perhitungan:

$$
\text { Ketuntasan klasikal }=\frac{m}{M} \times 100 \%
$$

Keterangan:

$$
\begin{aligned}
& \mathrm{M}=\text { Jumlah seluruh peserta } \\
& \mathrm{m}=\text { Jumlah peserta } \\
& \% \quad=\text { Tingkat prosentase yang dicapai }
\end{aligned}
$$

Kriteria:

Baik Sekali (A) : $90<\mathrm{A} \leq 100$

Baik (B) $\quad$ : $70<\mathrm{B} \leq 89$

Cukup (C) $\quad: 60<\mathrm{C} \leq 79$

Kurang $(\mathrm{K}) \quad: \leq 60$

Sedangkan Untuk mengetahui tingkat keberhasilan penelitian tindakan sekolah ini apabila:

1. Meningkatnya kompetensi guru dalam menyusun soal tes semester pada kategori baik dan baik sekali sebanyak $85 \%$.

2. Meningkatnya keaktifan belajar peserta didik pada kategori baik dan baik sekali sebanyak $85 \%$

\section{HASIL PENELITIAN}

Pelaksanaan siklus I dilakukan pada tanggal 23 Januari 2021.

Berdasarkan hasil kerja kelompok ini peneliti menilai perangkat penyusunan soal tes semester yang telah dilakukan guru. Untuk lebih jelasnya diperoleh data yang digambarkan dalam tabel dan diagram berikut: 
Tabel 1. Kompetensi Guru Dalam Menyusun Soal Tes Semester Siklus I

\begin{tabular}{|c|c|c|c|}
\hline \multirow{2}{*}{ Nilai } & \multicolumn{2}{|c|}{ Siklus I } & \multirow{2}{*}{ Kategori } \\
\cline { 2 - 3 } & Guru & $\%$ & \\
\hline $90 \%-100 \%$ & 4 & $22 \%$ & Baik sekali \\
\hline $70 \%-89 \%$ & 8 & $44 \%$ & Baik \\
\hline $50 \%-69 \%$ & 5 & $28 \%$ & Cukup \\
\hline$\leq 49 \%$ & 1 & $6 \%$ & Kurang \\
\hline Jumlah & 18 & $100 \%$ & \\
\hline
\end{tabular}

Dari tabel di atas dapat diketahui kompetensi guru dalam menyusun soal tes semester pada siklus I dimana pada kategori baik sekali sebanyak 4 guru atau $22 \%$, kategori baik sebanyak 8 guru atau 44\%, kategori cukup sebanyak 5 guru atau 28\%, kategori kurang sebanyak 1 guru atau 6\%. Sedangkan pengkategorian masing aspek dapat dilihat pada tabel sebagai berikut:

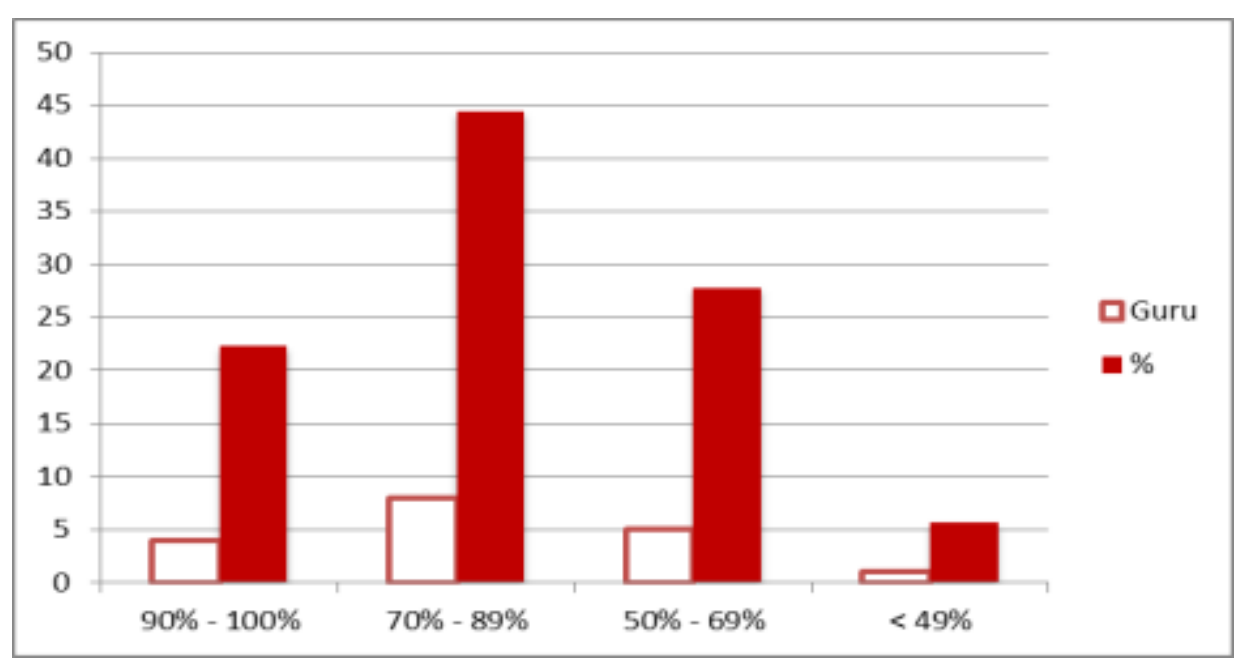

Gambar 2. Diagram Batang Kompetensi Guru Dalam Menyusun Soal Tes Semester Siklus I

Dari tabel dan diagram di atas menunjukkan kompetensi guru dalam menyusun soal tes semester kurang baik dan perlu ada peningkatan tindakan dalam supervisi manajerial yang dilakukan peneliti pada siklus berikutnya

Setelah mengobservasi peserta atau guru selama proses pelaksanaan kerj akelompok dengan menggunakan instrumen observasi yang dipegang kolabolator di dapat nilai dari keaktifan peserta terutama yang terkait dengan keaktifan guru dalam mendengarkan 
penjelasan supervisor, keaktifan guru dalam bertanya, dan keaktifan guru dalam kerja kelompok, keaktifan guru dalam diskusi dan keaktifan guru dalam dalam mengontari. Untuk lebih jelasnya diperoleh data yang digambarkan dalam tabel dan diagram berikut:

Tabel 2. Aktivitas Guru dalam Kerja Kelompok Siklus I

\begin{tabular}{|c|c|c|c|}
\hline \multirow{2}{*}{$\begin{array}{c}\text { Nilai } \\
\text { Keaktifan }\end{array}$} & \multicolumn{2}{|c|}{ Siklus I } & \multirow{2}{*}{ Kategori } \\
\cline { 2 - 3 } & Guru & $\%$ & \\
\hline $17-20$ & 5 & $28 \%$ & Sangat Aktif \\
$14-16$ & 6 & $33 \%$ & Aktif \\
\hline $11-13$ & 4 & $22 \%$ & Cukup \\
$8-10$ & 3 & $17 \%$ & Kurang \\
$5-7$ & 0 & $0 \%$ & Tidak Aktif \\
\hline Jumlah & 18 & $100 \%$ & \\
\hline
\end{tabular}

Dari tabel di atas dapat diketahui aktivitas guru dalam metode kerja kelompok pada siklus I dimana pada kategori Sangat Aktif sebanyak 5 guru atau 28\%, kategori aktif sebanyak 6 guru atau 33\%, kategori cukup sebanyak 4 guru atau 22\%, kategori kurang sebanyak 3 guru atau $17 \%$.

\section{Siklus II}

Pelaksanaan siklus II dilakukan pada tanggal 18 Februari 2021 siklus ini dilakukan beberapa tahapan diantaranya:

Berdasarkan hasil metode kerja kelompok ini peneliti menilai perangkat penyusunan soal tes semester yang telah dilakukan guru. Untuk lebih jelasnya diperoleh data yang digambarkan dalam tabel dan diagram berikut:

Tabel 3. Kompetensi Guru Dalam Menyusun Soal Tes Semester Siklus II

\begin{tabular}{|c|c|c|c|}
\hline \multirow{2}{*}{ Nilai } & \multicolumn{2}{|c|}{ Siklus II } & \multirow{2}{*}{ Kategori } \\
\cline { 2 - 4 } & Guru & $\%$ & \\
\hline $90 \%-100 \%$ & 8 & $44 \%$ & Baik sekali \\
\hline $70 \%-89 \%$ & 9 & $50 \%$ & Baik \\
\hline $50 \%-69 \%$ & 1 & $6 \%$ & Cukup \\
\hline$\leq 49 \%$ & 0 & $0 \%$ & Kurang \\
\hline Jumlah & 18 & $100 \%$ & \\
\hline
\end{tabular}


Dari tabel di atas dapat diketahui kompetensi guru dalam menyusun soal tes semester pada siklus II dimana pada kategori baik sekali sebanyak 8 guru atau $44 \%$ naik dari siklus I yaitu 4 guru atau 22\%, kategori baik sebanyak 9 guru atau 50\% naik dari siklus I yaitu 8 guru atau $44 \%$, kategori cukup sebanyak 1 guru atau $6 \%$ turun dari siklus I yaitu 5 guru atau 28\%, kategori kurang sebanyak tidak ada guru atau $0 \%$ turun dari siklus I yaitu 1 guru atau 6\%. Dari tabel dan diagram di atas menunjukkan profesionalitas guru dalam menyusun perangkat pembelajaran sudah baik

Setelah mengobservasi peserta atau guru selama proses pelaksanaan kerj akelompok dengan menggunakan instrumen observasi yang dipegang kolabolator di dapat nilai dari keaktifan peserta terutama yang terkait dengan keaktifan guru dalam mendengarkan penjelasan supervisor, keaktifan guru dalam bertanya, dan keaktifan guru dalam kerja kelompok, keaktifan guru dalam diskusi dan keaktifan guru dalam dalam mengontari. Untuk lebih jelasnya diperoleh data yang digambarkan dalam tabel dan diagram berikut:

Tabel 4. Aktivitas Guru dalam Metode Kerja Kelompok Siklus II

\begin{tabular}{|c|c|c|c|}
\hline \multirow{2}{*}{$\begin{array}{c}\text { Nilai } \\
\text { Keaktifan }\end{array}$} & \multicolumn{2}{|c|}{ Siklus II } & \multirow{2}{*}{ Kategori } \\
\cline { 2 - 3 } & Guru & $\%$ & \\
\hline $17-20$ & 7 & $39 \%$ & Sangat Aktif \\
$14-16$ & 9 & $50 \%$ & Aktif \\
\hline $11-13$ & 2 & $11 \%$ & Cukup \\
$8-10$ & 0 & $0 \%$ & Kurang \\
$5-7$ & 0 & $0 \%$ & Tidak Aktif \\
\hline Jumlah & 18 & $100 \%$ & \\
\hline
\end{tabular}

Dari tabel di atas dapat diketahui aktivitas guru dalam metode kerja kelompok pada siklus II dimana pada kategori sangat aktif sebanyak 7 guru atau 39\% naik dari siklus I yaitu 5 guru atau 28\%, kategori aktif sebanyak 9 guru atau 50\% naik dari siklus I yaitu 6 guru atau $33 \%$, kategori cukup sebanyak 2 guru atau $11 \%$ turun dari siklus I yaitu 4 guru atau 22\%, kategori kurang tidak guru atau 0\% turun dari siklus I yaitu 3 guru atau 17\%, dan kategori tidak aktif tidak ada guru atau $0 \%$ sama dengan siklus I.

\section{PEMBAHASAN}

Berdasarkan hasil penelitian secara keseluruhan terjadi kompetensi guru dalam menyusun soal tes semester setelah dilakukan pelaksanaan metode kerja kelompok di SDN Kalibanteng 
Kulon 02 Kota Semarang tahun pelajaran 2020/2021, begitu juga terjadi peningkatan aktivitas guru dalam mengikuti metode kerja kelompok, maka dari hasil pembahasan dapat diketahui data kompetensi guru dalam menyusun soal tes semester setelah dilakukan metode kerja kelompok. Untuk memperjelas pembahasan tersebut dapat dilihat data sebagai berikut:

1. Kompetensi Guru dalam Menyusun Soal Tes Semester

Kompetensi guru dalam menyusun soal tes semester di SDN Kalibanteng Kulon 02 Kota Semarang tahun pelajaran 2020/2021, terjadi peningkatan per siklusnya, untuk lebih jelasnya dapat di lihat dalam tabel dan grafik berikut:

Tabel 5. Perbandingan Kategori Kompetensi Guru dalam Menyusun Soal Tes Semester Siklus I dan Siklus II

\begin{tabular}{|c|c|c|c|c|c|}
\hline \multirow{2}{*}{ Nilai } & \multicolumn{2}{|c|}{ Siklus I } & \multicolumn{2}{c|}{ Siklus II } & \multirow{2}{*}{ Kategori } \\
\cline { 2 - 5 } & Guru & $\%$ & Guru & $\%$ & \\
\hline $90 \%-100 \%$ & 4 & $22 \%$ & 8 & $44 \%$ & Baik Sekali \\
\hline $70 \%-89 \%$ & 8 & $44 \%$ & 9 & $50 \%$ & Baik \\
\hline $50 \%-69 \%$ & 5 & $28 \%$ & 1 & $6 \%$ & Cukup \\
\hline$\leq 40 \%$ & 1 & $6 \%$ & 0 & $0 \%$ & Kurang \\
\hline Jumlah & 18 & $100 \%$ & 18 & $100 \%$ & \\
\hline
\end{tabular}

Berdasarkan tabel dan grafik di atas menunjukkan Kompetensi guru dalam menyusun soal tes semester pada siklus I ada 12 guru atau 66\% dan pada siklus II ada 17 guru atau 94\%, hasil tersebut sudah mencapai indikator yang ditentukan yaitu terjadi peningkatan kompetensi guru dalam menyusun soal tes semester di SDN Kalibanteng Kulon 02 Kota Semarang tahun pelajaran 2020/2021 dengan pelaksanaan metode kerja kelompok pada siklus I, siklus II tiap individu yang mencapai $85 \%$ dari seluruh jumlah guru.

Berdasarkan hasil penelitian yang telah dikemukakan di atas, pada pelaksanaan tindakan siklus I dan siklus II dapat diketahui perubahan-perubahan hasil peningkatan kompetensi guru dalam menyusun soal tes semester di SDN Kalibanteng Kulon 02 Kota Semarang tahun pelajaran 2020/2021.

2. Aktivitas Guru dalam Metode kerja kelompok

Aktivitas guru SDN Kalibanteng Kulon 02 Kota Semarang tahun pelajaran 2020/2021 dalam metode kerja kelompok mengalami kenaikan per siklusnya, untuk lebih jelasnya dapat dilihat dalam tabel dan grafik berikut: 
Tabel 6. Aktivitas Guru dalam Metode kerja kelompok Siklus I dan Siklus II

\begin{tabular}{|c|c|c|c|c|c|}
\hline \multirow{2}{*}{$\begin{array}{c}\text { Nilai } \\
\text { Aktivitas }\end{array}$} & \multicolumn{2}{|c|}{ Siklus I } & \multicolumn{2}{c|}{ Siklus II } & \multirow{2}{*}{ Kategori } \\
\cline { 2 - 5 } & Guru & $\%$ & Guru & $\%$ & \\
\hline $17-20$ & 5 & $28 \%$ & 7 & $39 \%$ & Sangat Aktif \\
$14-16$ & 6 & $33 \%$ & 9 & $50 \%$ & Aktif \\
\hline $11-13$ & 4 & $22 \%$ & 2 & $11 \%$ & Cukup \\
$8-10$ & 3 & $17 \%$ & 0 & $0 \%$ & Kurang \\
$5-7$ & 0 & $0 \%$ & 0 & $0 \%$ & Tidak Aktif \\
\hline Jumlah & 18 & $100 \%$ & 18 & $100 \%$ & \\
\hline
\end{tabular}

Berdasarkan tabel di atas menunjukkan aktivitas guru SDN Kalibanteng Kulon 02 Kota Semarang tahun pelajaran 2020/2021dalam metode kerja kelompok pada siklus I ada 11 guru atau $61 \%$ dan siklus II ada 16 guru atau 89\%, hasil tersebut sudah mencapai indikator yang ditentukan yaitu terjadi peningkatan aktivitas guru SDN Kalibanteng Kulon 02 Kota Semarang tahun pelajaran 2020/2021 dalam metode kerja kelompok tiap individu pada kategori aktif dan sangat aktif yang mencapai $85 \%$ dari seluruh jumlah guru.

Grafik di atas menunjukkan telah terjadi peningkatan aktivitas guru SDN Kalibanteng Kulon 02 Kota Semarang tahun pelajaran 2020/2021 dalam mengikuti metode kerja kelompok setiap siklusnya sehingga telah mencapai indikator yang ditentukan yaitu $85 \%$.

Hasil tabel di atas juga menunjukkan usaha yang dilakukan kepala sekolah dalam pelaksanaan metode kerja kelompok sebagai upaya peningkatan kompetensi guru dalam menyusun soal tes semester di SDN Kalibanteng Kulon 02 Kota Semarang tahun pelajaran 2020/2021 dengan penelitian tindakan sekolahnya telah dapat meningkatkan kompetensi guru dalam menyusun soal tes semester di SDN Kalibanteng Kulon 02 Kota Semarang tahun pelajaran 2020/2021, fokus tindakan kepala yang dilakukan dengan menjadi seorang motivator dan pembimbing yang baik bagi guru.

Berdasarkan teori tersebut maka penelitian ini ada kesuaian antara data lapangan dan teori yang ada dan Hipotesis tindakan dalam penelitian ini yang menyatakan pelaksanaan metode kerja kelompok dapat meningkatkan kompetensi guru dalam menyusun soal tes semester di SDN Kalibanteng Kulon 02 Kota Semarang tahun pelajaran 2020/2021 terbukti dan diterima. 


\section{SIMPULAN}

Dari hasil penelitian dan pembahasan dapat diambil kesimpulan sebagai berikut :

1. Pelaksanaan metode kerja kelompok sebagai upaya peningkatan kompetensi guru dalam menyusun soal tes semester di SDN Kalibanteng Kulon 02 Kota Semarang tahun pelajaran 2020/2021 dilakukan dengan melakukan pembagian kelompok pada guru dalam supervisi yang dilakukan kepala sekolah.

2. Pelaksanaan metode kerja kelompok dapat meningkatkan kompetensi guru dalam menyusun soal tes semester di SDN Kalibanteng Kulon 02 Kota Semarang tahun pelajaran 2020/2021

\section{SARAN}

Berdasarkan hasil peneliti yang me nununjukkan pelaksanaan metode kerja kelompok dapat meningkatkan kompetensi guru dalam menyusun soal tes semester maka melalui kesempatan ini penulis mengajukan beberapa saran:

1. Disarankan dalam menyusun tes hasil belajar akhir semester hendaknya menyelenggarakan metode kerja kelompok agar kerja sama guru dan saling tukar informasidapat terbina dengan baik dalam mewujudkan meningkatkan mutu dari hasil penyusunan tes semester guru.

2. Kepada semua guru dalam melaksanakan tugas untuk menyusun tes sangat perlu mengadakan kerja sama dan bertukar pikiran dengan guru mata pelajaran lain.

3. Bagi peneliti lain dapat melaksanakan penelitian yang lebih lanjut, penelitian ini juga dapat dikembangkan kegiatan metode kerja kelompok dengan pembahasan yang lain dalam upaya meningkatkan kompetensi guru.

\section{DAFTAR PUSTAKA}

Ali, Muhammad, 2006, Guru dalam Proses Belajar Mengajar, Bandung: Sinar Baru Algensindo

Arikunto, Suharsimi, 1993, Organisasi Administrasi Pendidikan Teknologi dan Kejuruan, Jakarta: PT. Raja Grafindo Persada

\section{----------, 2006, Prosedur Penelitian Suatu Pendekatan Praktek, Jakarta: Rineka Cipta}

Asmani, Jamal Ma'ruf, 2009, Tujuh Kompetensi Guru Menyenangkan dan Profesional , Jogjakarta: Power Book

Ayuni, M., 2019, Peningkatan Kemampuan Guru dalam Menyusun Soal Evaluasi Melalui Kegiatan In House Training IHT. Journal of Classroom Action Research, 61 
Indrafachrudi, Soekarto, 2013, Mengantar Bagaimana Memimpin Sekolah Yang Baik, Jakarta: Ghia Indonesia

Mudjijo, 2010, Tes Hasil Belajar, Jakarta: Bumi Aksara

Mulyasa, E. , 2012, Standar Kompetensi Sertifikasi Guru,Bandung, PT.Remaja Rosdakarya

----------, 2013, Manajemen Berbasis Sekolah: Konsep, Strategi dan Implementasi, Bandung: Rosdakarya

Peraturan Menteri Pendidikan Nasional Nomor 16 Tahun 2007 Tentang Standar Kualifikasi Akademik Dan Kompetensi Guru

Pidarta, Made, 2009, Supervisi Pendidikan Kontekstual, Jakarta: Rineka Cipta

Purwanto, Ngalim, 2012, Prinsip-prinsip dan Teknik Evaluasi Pengajaran, Bandung : Remaja Rosdakarya

Rahman, Nazarudin, 2011, Regulasi Pendidikan, Yogyakarta: Pustaka Felicha

Ramayulis, 2005, Metodologi Pendidikan, Jakarta : Kalam Mulia

Ramayulis, 2014, Ilmu Pendidikan Islam, Jakarta: Kalam Mulia

Sagala, Syaiful, 2010, Supervisi Pembelajaran dalam Profesi Pendidikan, Bandung: Alfabeta

Sahertian Piet A., 2010, Konsep-konsep Dasar dan Teknik Supervisi Pendidikan Dalam Rangka Pengembangan Sumber Daya Manusia, Jakarta: Rineka Cipta

Suwarno, Wiji, 2009, Dasar-dasar Ilmu Pendidikan, Jogjakarta: PT. Ar-Ruzz Media Grup

Undang - Undang Republik Indonesia nomor 14 tahun 2005 tentang Guru dan Dosen serta Undang-Undang Republik Indonesia nomor 20 tahun 2003 tentang SISDIKNAS,Bandung: Citra Umbara, 2006

Usman, Moh. Uzer, 2012, Menjadi Guru Profesional, Bandung: PT. Remaja Rosdakarya

Warso, Wasisto Dwi Doso, Agus, 2016, Penelitian kepengawasan dan Tindakan Sekolah, Klaten: Widyapustaka Publisher.

Zuhairini, dkk., 2011, Metodologi Pendidikan Agama, Solo: Ramadhani 